\title{
Phosphorus fractions and correlation with soil attributes in a chronosequence of agricultural under no-tillage
}

\section{Frações de fósforo e correlação com atributos edáficos em uma cronossequência de agricultura sob plantio direto}

\author{
Jean Sérgio Rosset ${ }^{1 *}$; Roni Fernandes Guareschi²; \\ Luiz Alberto da Silva Rodrigues Pinto ${ }^{3}$; Marcos Gervasio Pereira ${ }^{4}$; \\ Maria do Carmo Lana ${ }^{5}$
}

\begin{abstract}
In no-tillage (NT) soils, changes in the quantity and quality of soil organic matter (SOM) have been observed over time. These changes can interfere with the dynamics of P in surface soil layers. Thus, the objectives of this study were: to evaluate the organic and inorganic fractions of $\mathrm{P}$ and their degree of lability (labile, moderately labile, and moderately recalcitrant) in an Oxisol under NT for 6 years $\left(\mathrm{NT}_{6}\right)$, 14 years $\left(\mathrm{NT}_{14}\right)$, and 22 years $\left(\mathrm{NT}_{22}\right)$ and cultivated with a succession of soybean and corn/wheat. The fractions were evaluated for 16 years of NT, with the last four years under integrated corn second crop and Brachiaria $\left(\mathrm{NT}_{16+\mathrm{B}}\right)$. We also analyzed an area of native forest, as well as analyzing the correlations between the results of the $\mathrm{P}$ fractions of these areas with other attributes such as total carbon content, vegetable waste deposited on the ground, phosphorus and humic fractions remaining in SOM. From each of the areas, samples were collected at $0.00-0.05 \mathrm{~m}$ and $0.05-0.10 \mathrm{~m}$. A completely randomized design with 5 replicates was used. Management of phosphorus fertilization and SOM following adoption of the NT of time (6 to 22 years) increased the levels of all fractions of inorganic $\mathrm{P}(0.0$ to $0.10 \mathrm{~m})$, as well as the fractions of labile $(0.05-0.10 \mathrm{~m})$, moderately labile $(0.0-0.10 \mathrm{~m})$, and moderately recalcitrant $(0.05-0.10 \mathrm{~m})$ organic phosphorus. The correlation matrix shows interactions between the evaluated soil attributes, especially between inorganic phosphorus fractions and fulvic and humic acids and between the moderately recalcitrant organic phosphorus and humin fraction.
\end{abstract}

Key words: Oxisol. Organic phosphorus. Phosphorus sorption. Soil organic matter.

\section{Resumo}

Em solos sob sistema de plantio direto (SPD) tem sido observado alterações na quantidade e qualidade da matéria orgânica do solo (MOS) ao longo do tempo, o que pode interferir na dinâmica do P nas camadas superficiais do solo. Dessa forma, os objetivos deste estudo foram: avaliar as frações inorgânicas e orgânicas de P e o grau de labilidade destas (lábil, moderamente lábil e moderadamente resistente) de um Latossolo Vermelho eutroférrico sob sistema de plantio direto (SPD) com 6 anos ( $\left.\mathrm{SPD}_{6}\right), 14$

\footnotetext{
${ }^{1}$ Prof. Adjunto IV, Universidade Estadual de Mato Grosso do Sul, UEMS, Mundo Novo, MS, Brasil. E-mail: rosset@uems.br

2 Pós-Doutorando em Fitotecnia, Departamento de Ciclagem de Nutrientes, Universidade Federal Rural do Rio de Janeiro, UFRRJ, Seropédica, RJ, Brasil. E-mail: guareschiecotarelli@hotmail.com

${ }_{3}^{3}$ Discente do Curso de Agronomia, UFRRJ, Seropédica, RJ, Brasil. E-mail: 1_arodrigues@yahoo.com.br

${ }^{4}$ Prof. Adjunto, Departamento de Solos, UFRRJ, Bolsista CNPq e Cientista do Nosso Estado da FAPERJ, Seropédica, RJ, Brasil. E-mail: gervasio@ufrrj.br

${ }^{5}$ Prof $^{a}$ Associada, Centro de Ciências Agrárias, CCA, Universidade Estadual do Oeste do Paraná, UNIOESTE, Bolsista CNPq, Marechal Cândido Rondon, PR, Brasil. E-mail: maria.lana@unioeste.br

* Author for correspondence
} 
anos $\left(\mathrm{SPD}_{14}\right)$ e 22 anos $\left(\mathrm{SPD}_{22}\right)$ na sucessão soja, milho/trigo; 16 anos de $\mathrm{SPD}$, sendo nos últimos quatro anos com integração milho segunda safra e Urochloa $\left(\mathrm{SPD}_{16+\mathrm{B}}\right)$ e uma área de mata nativa; e analisar correlações entre os resultados das frações de $\mathrm{P}$ dessas áreas com outros atributos, tais como, carbono total, resíduos vegetais depositados sobre o solo, fósforo remanescente e frações húmicas da MOS. Em cada uma das áreas foram coletadas amostras nas camadas de 0,00-0,05 m e 0,05-0,10 m. O delineamento utilizado foi inteiramente casualizado, com 5 repetições. O manejo da adubação fosfatada e da MOS em função do tempo de adoção do SPD (6 para 22 anos) aumentou os teores de todas as frações de P inorgânico $(0,0-0,10 \mathrm{~m})$, bem como, as frações de fósforo orgânico lábil $(0,05-0,10 \mathrm{~m})$, moderadamente lábil $(0,0-0,10 \mathrm{~m})$ e moderadamente resistente $(0,05-0,10 \mathrm{~m})$. Através da matriz de correlação podem-se verificar interações entre os atributos do solo avaliados, principalmente entre as frações de fósforo inorgânico e os ácidos fúlvicos e húmicos, e entre o fósforo orgânico moderadamente resistente e a fração humina.

Palavras-chave: Latossolo Vermelho. Fósforo orgânico. Adsorção de fósforo. Matéria orgânica do solo.

\section{Introduction}

The increase in soil organic matter (SOM) quantity and quality, with increasing years in which no-tillage (NT) is practiced, can affect soil phosphorus (P) availability and the dynamics of soil $\mathrm{P}$ fractions. Soluble organic compounds originating from SOM decomposition may compete with phosphates for adsorption sites, and/or form complexes with metal cations, such as iron and aluminum, removing them from the adsorption surface (GUPPY et al., 2005). In addition, sorption of SOM compounds may increase the negative charges at the soil surface, making phosphate adsorption more difficult.

Phosphorus fertilizers are frequently applied to the soil surface, resulting in $\mathrm{P}$ accumulation in superficial soil layers. The soil P fractionation may therefore be used to determine the influence of NT on P lability. P fractionation allows the separation of labile, moderately labile, and non-labile phosphorus forms, and further illustrates the dynamics of $\mathrm{P}$ availability (SANTOS et al., 2008).

The use of the Bowman and Cole (1978) and Bowman (1989) methods for extraction of inorganic (Pi) and organic phosphorus (Po) has been proposed by several authors (PARTELLI et al., 2009; BEUTLER, 2012; DUDA et al., 2013; OLIVEIRA et al., 2014; BEUTLER et al., 2015; BEZERRA et al., 2015). These methods allow the extraction of labile, moderately labile, moderately recalcitrant, and recalcitrant $\mathrm{P}$ fractions, using different extractors $\left(\mathrm{NaHCO}_{3}, \mathrm{NaOH}\right.$, and $\left.\mathrm{H}_{2} \mathrm{SO}_{4}\right)$, therefore separating soil $\mathrm{P}$ into fractions of different plant availability. Po fractions are calculated as the difference between $\mathrm{Pi}$ and the total phosphorus, resulting from an extraction using all extractors (BEUTLER, 2012). $\mathrm{NaHCO}_{3}$ extracts labile $\mathrm{Pi}$ and Po fractions, which have higher availability to plants (GATIBONI et al., 2007; GONÇALVES; MEURER, 2009). P fractions obtained through acid extraction (1.79 $\left.\mathrm{mol} \mathrm{L}^{-1} \mathrm{H}_{2} \mathrm{SO}_{4}\right)$ are considered moderately labile (BOWMAN; COLE, 1978), and through alkaline extraction $(\mathrm{NaOH})$, moderately recalcitrant (BOWMAN; COLE, 1978).

Some studies have investigated $\mathrm{P}$ fractionation in highly weathered soils under NT (SILVA et al., 2003; GALVANI et al., 2008; OLIBONE; ROSOLEM, 2010; CARNEIRO et al., 2011; BEUTLER, 2012). However, the results are conflicting. Studies of the effect of different $P$ sources, and modes of application in NT areas, have observed that $\mathrm{P}$ application (independent of the source and mode of application) increased soil Po concentrations (GALVANI et al., 2008; OLIBONE; ROSOLEM, 2010). However, when soils under NT and native Cerrado were compared, $\mathrm{P}$ fertilization was observed to result in decreased Po and increased $\mathrm{Pi}$ concentrations in NT areas when compared to untreated soils from Cerrado (SILVA et al., 2003; CARNEIRO et al., 2011; BEUTLER, 2012; RODRIGUES, 2013). 
Recently, there has been an increase in studies of soil phosphorus dynamics in NT areas with croplivestock integration (CLI) (BEUTLER et al., 2015; BEZERRA et al., 2015). These studies showed higher availability of the Pi and Po fractions in NT with and without CLI (BEZERRA et al., 2015). The authors attributed this to higher input of plant material in CLI systems due to the planting of Urochloa, cattle manure left randomly throughout the area, and the application of fertilizers. Similarly, Beutler et al. (2015) compared soil P fractionation in areas of CLI, pasture, and native Cerrado, and observed higher labile, moderately labile, and moderately recalcitrant $\mathrm{P}$ fractions in CLI than in the remaining studied areas.

This indicates possible correlations between SOM and its fractions, phosphorus fertilization management, and soil phosphorus dynamics, in areas under conservationist systems. However, further studies are needed to understand the $\mathrm{P}$ availability variations with different types of NT and lengths of time in which it is implicated.

The aim of this study was: i) to analyze the residual $\mathrm{P}$ and inorganic and organic $\mathrm{P}$ fractions and their degree of lability (labile, moderately labile, and moderately recalcitrant) in a eutropherric Red Latosol in an NT chronosequence, and ii) to analyze the correlations between $\mathrm{P}$ fractions and total carbon, surface plant residue on the soil (SPR), and SOM humic fractions for the studied areas.

\section{Material and Methods}

The study was performed in five areas within a rural property of the municipality of Guaíra, Western state of Paraná, Brazil (Figure 1).

Figure 1. Location of the municipality of Guaira-PR. Source: Elaborated by the authors.

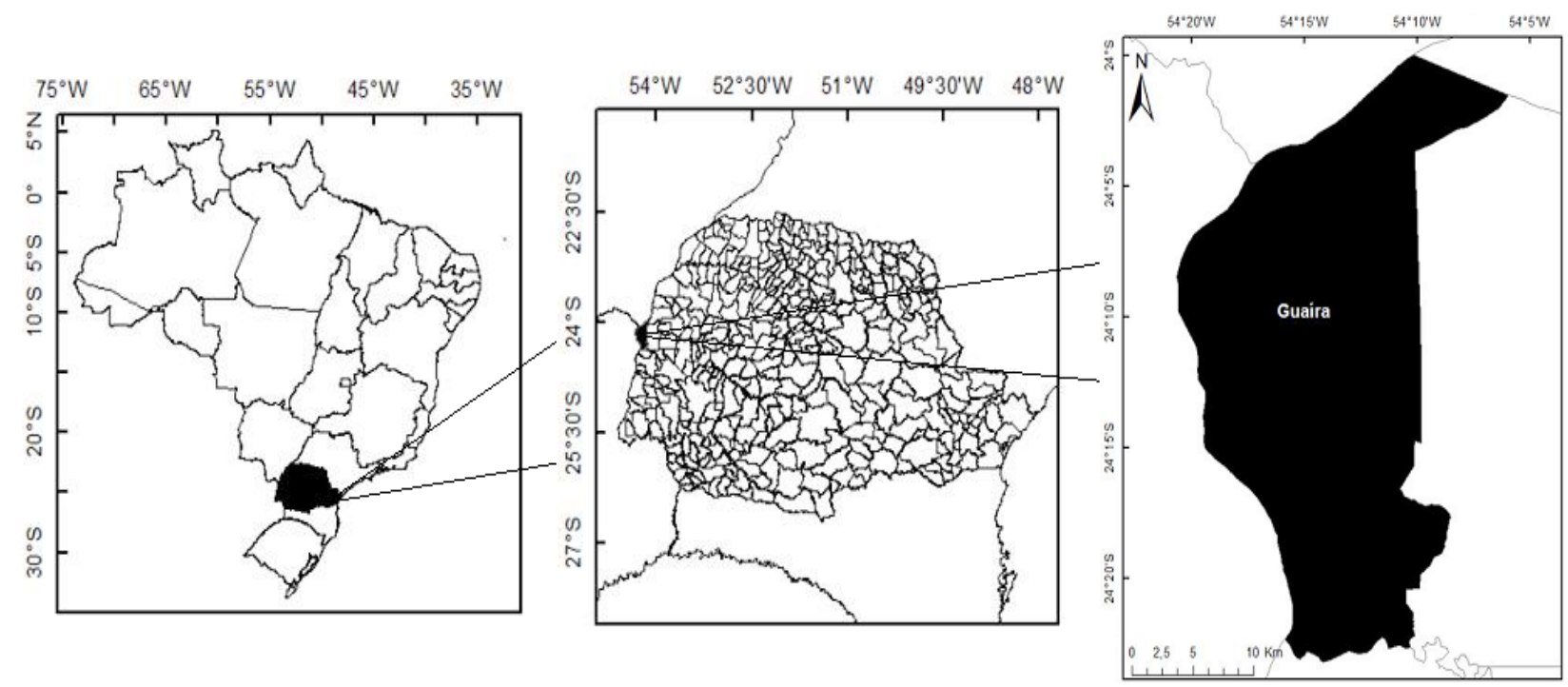

The region's climate is subtropical (Cfa) according to the Köppen climate classification. A detailed Paraná soil survey (BHERING; SANTOS, 2008) states that the soil at the study areas is a typical eutropherric Red Latosol, with a very claylike texture (EMBRAPA, 2013).
Four areas under agricultural management, and a reference area (Native Forest; NF) without anthropic action, were evaluated, for a total of five different systems. The four managed areas were as follows: NT for 6 years (transition phase; $\mathrm{NT}_{6}$ ), 14 years (consolidation phase; $\mathrm{NT}_{14}$ ), or 22 years 
(maintenance phase; $\mathrm{NT}_{22}$ ), with a soya (summer) and corn/wheat (winter) crop succession, and NT for 16 years, of which 12 years had the same crop succession and 4 years included corn intercropping with Brachiaria ruziziensis as winter crops (consolidation phase; $\mathrm{NT}_{16+\mathrm{B}}$ ). A detailed description of the areas is presented in Table 1.

Table 1. History, description, and location of study areas.

\begin{tabular}{|c|c|}
\hline $\begin{array}{l}\text { Management } \\
\text { system }\end{array}$ & Description \\
\hline $\mathrm{NT}_{6}$ & $\begin{array}{l}20 \text { ha; } 270 \mathrm{~m} \text { altitude, } 24^{\circ} 09^{\prime} 092^{\prime \prime} \text { South }(\mathrm{S}) \text { and } 54^{\circ} 13^{\prime} 368^{\prime \prime} \text { West }(\mathrm{W}) \text {. Transition phase, with six } \\
\text { years of NT. }\end{array}$ \\
\hline $\mathrm{NT}_{14}$ & 17 ha; $298 \mathrm{~m}$ altitude, $24^{\circ} 09^{\prime} 938^{\prime \prime} \mathrm{S}$ and $54^{\circ} 14^{\prime} 190^{\prime \prime} \mathrm{W}$. Consolidation phase, with 14 years of NT. \\
\hline $\mathrm{NT}_{22}$ & 77 ha; $297 \mathrm{~m}$ altitude, $24^{\circ} 15^{\prime} 454^{\prime \prime} \mathrm{S}$ and $54^{\circ} 10^{\prime} 361^{\prime \prime} \mathrm{W}$. Maintenance phase, with 22 years of NT. \\
\hline $\mathrm{NT}_{16+\mathrm{B}}$ & $\begin{array}{l}20 \text { ha; } 281 \mathrm{~m} \text { altitude, } 24^{\circ} 09^{\prime} 136^{\prime \prime} \mathrm{S} \text { and } 54^{\circ} 13^{\prime} 676^{\prime \prime} \mathrm{W} \text {. Consolidation phase, with } 16 \text { years of NT. } \\
\text { First } 12 \text { years of NT with soya/corn-wheat succession, followed by four years of corn intercropping } \\
\text { with Brachiaria ruziziensis in winter crops. }\end{array}$ \\
\hline $\mathrm{NF}$ & $\begin{array}{l}2 \text { ha; Native vegetation area (Atlantic Forest -Semideciduous Stational Forest), } 295 \mathrm{~m} \text { altitude, } \\
24^{\circ} 11^{\prime} 029^{\prime \prime} \mathrm{S} \text { and } 54^{\circ} 11^{\prime} 898^{\prime \prime} \mathrm{W} \text {, used as reference. }\end{array}$ \\
\hline
\end{tabular}

Following conversion from the conventional system (CS) to NT, all areas were cultivated with a soya (summer) and corn/wheat (winter) crop rotation, except for $\mathrm{NT}^{16+\mathrm{B}}$, in which corn intercropping with Brachiaria ruziziensis was introduced in the last four years to increase straw production (essential to be considered NT) for the following soya crop. In all NT areas, the fertilizations applied during the last five years of soya/corn-wheat crop succession consisted of $270 \mathrm{~kg} \mathrm{ha}^{-1}$ of 02-20-18, and inoculation with Bradyrhizobium japonicum (150 mL of inoculant liquid per $50 \mathrm{~kg}$ seeds) for the soya crop, and $270 \mathrm{~kg} \mathrm{ha}^{-1}$ of 10-15-15 for the corn-wheat crop. Additionally, $1.7 \mathrm{Mg} \mathrm{ha}^{-1}$ lime was applied every four years, except in $\mathrm{NT}_{14}$, which received no soil corrections following the conversion from CS to NT (1998).

In August 2012, a representative plot with 2000 $\mathrm{m}^{-2}$ was delimited in each area, and soil samples were collected randomly from the soil layers 0-0.05 and 0.05-0.10 m, using a spade with a straight cutting edge. In NT areas, $75 \%$ of the samples were collected between, and $25 \%$ within, planting rows. Five composite deformed soil samples were obtained (composed of 10 individual samples). The soil samples were air dried, the clods were crushed, and the samples were sieved through a $2 \mathrm{~mm}$ mesh, to obtain fine, air-dried soil (ADFS). This was then used for the soil chemical and particle size analysis, according to Embrapa (1997) (Table 2), and soil $\mathrm{P}$ fractionation. A completely randomized experimental design was used, with five replicates for each area.

Total organic and inorganic soil $\mathrm{P}$ fractions were determined according to Bowman (1989). Labile $\mathrm{P}$ fractions (extraction with $0.5 \mathrm{~mol} \mathrm{~L}^{-1}$ sodium bicarbonate, $\mathrm{pH}$ 8.5) were determined according to Bowman and Cole (1978) as modified by Duda (2000). Briefly, P fractionation was performed through sequential $\mathrm{P}$ extraction, using the same soil sample. Samples of $1 \mathrm{~g}$ ADFS were used. The first 
extraction was performed using $0.5 \mathrm{~mol} \mathrm{~L}^{-1}$ sodium bicarbonate $\left(\mathrm{NaHCO}_{3}\right), \mathrm{pH}$ 8.5, for extraction of labile $\mathrm{P}$. Labile $\mathrm{P}$ was quantified using a spectrophotometer (EMBRAPA, 1997). The second extraction was performed using concentrated sulfuric acid (1.79 $\left.\mathrm{mol} \mathrm{L}^{-1} \mathrm{H}_{2} \mathrm{SO}_{4}\right)$, for extraction of moderately labile $\mathrm{P}$. The third extraction was performed using $0.5 \mathrm{~mol} \mathrm{~L}^{-1}$ sodium hydroxide $(\mathrm{NaOH})$, for extraction of moderately recalcitrant $\mathrm{P}$.
Po concentrations in soil samples were calculated as the difference between the total $\mathrm{P}$ and inorganic $\mathrm{P}$ recovered in each extract. Total $\mathrm{P}(\mathrm{Pt})$ was determined in aliquots of the soil samples subjected to perchloric acid digestion, and Pi was determined in non-digested extracts. The organic P fraction of each extract is therefore calculated by subtracting the $\mathrm{P}$ content of non-digested extracts from the $\mathrm{P}$ content of digested extracts (BOWMAN, 1989).

Table 2. Soil chemical properties and particle size analysis for the study areas.

\begin{tabular}{|c|c|c|c|c|c|c|c|c|c|c|c|}
\hline \multirow{3}{*}{ *Areas } & $\mathrm{pH}$ & $\mathrm{Ca}$ & $\mathrm{Mg}$ & $\mathrm{K}$ & $\mathrm{Al}$ & $\mathrm{H}+\mathrm{Al}$ & $\mathrm{T}$ & $\mathrm{V}$ & Clay & Silt & Sand \\
\hline & $\mathrm{CaCl}_{2}$ & \multicolumn{6}{|c|}{ 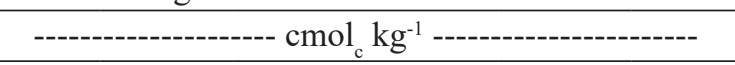 } & $---\%-$ & \multicolumn{3}{|c|}{-------- $\mathrm{g} \mathrm{kg}^{-1}$-------- } \\
\hline & \multicolumn{11}{|c|}{$0-0.05 \mathrm{~m}$} \\
\hline $\mathrm{NT}_{6}$ & 5.8 & 5.5 & 1.8 & 0.5 & 0.0 & 2.9 & 10.7 & 72.9 & 614 & 216 & 170 \\
\hline $\mathrm{NT}_{14}$ & 5.1 & 3.1 & 1.0 & 0.3 & 0.1 & 4.3 & 8.7 & 50.6 & 669 & 186 & 145 \\
\hline $\mathrm{NT}^{16+\mathrm{B}}$ & 6.0 & 5.6 & 1.1 & 0.5 & 0.0 & 2.6 & 9.8 & 73.5 & 618 & 209 & 173 \\
\hline $\mathrm{NT}_{22}$ & 6.0 & 6.3 & 1.3 & 0.6 & 0.0 & 3.2 & 11.4 & 71.9 & 623 & 276 & 101 \\
\hline \multirow[t]{2}{*}{$\mathrm{NF}$} & 6.4 & 8.6 & 1.0 & 0.4 & 0.0 & 2.7 & 12.7 & 78.7 & 617 & 265 & 118 \\
\hline & \multicolumn{11}{|c|}{$0.05-0.10 \mathrm{~m}$} \\
\hline $\mathrm{NT}_{6}$ & 5.5 & 4.2 & 1.2 & 0.3 & 0.0 & 3.7 & 9.4 & 60.6 & 613 & 220 & 167 \\
\hline $\mathrm{NT}_{14}$ & 4.8 & 2.2 & 0.6 & 0.2 & 0.5 & 5.4 & 8.4 & 35.7 & 698 & 157 & 145 \\
\hline $\mathrm{NT}_{16+\mathrm{B}}$ & 5.5 & 5.2 & 0.7 & 0.3 & 0.0 & 3.1 & 9.3 & 66.7 & 619 & 210 & 170 \\
\hline $\mathrm{NT}_{22}$ & 5.5 & 5.3 & 1.1 & 0.4 & 0.0 & 4.3 & 11.1 & 61.3 & 628 & 271 & 101 \\
\hline $\mathrm{NF}$ & 6.3 & 7.9 & 0.9 & 0.3 & 0.0 & 2.2 & 11.3 & 80.5 & 620 & 256 & 125 \\
\hline
\end{tabular}

* no tillage system $(\mathrm{NT})$ for 6 years $\left(\mathrm{NT}_{6}\right), 14$ years $\left(\mathrm{NT}_{14}\right), 22$ years $\left(\mathrm{NT}_{22}\right)$, or 16 years of which four included corn intercropping with Brachiaria used in interim harvest $\left(\mathrm{NT}_{16+\mathrm{B}}\right)$; and one native forest area (NF).

Source: Rosset (2015) and Rosset et al. (2014).

Correlations between the different $\mathrm{P}$ fractions and the amount of plant residues deposited on the soil (SPR), total carbon concentration (C), residual $\mathrm{P}$, and SOM humic fractions, were analyzed using the Pearson product moment correlation coefficient.
The SPR, total C, residual phosphorus, and SOM humic fractions data were obtained from Rosset (2015) and Rosset et al. (2014), determined for the same areas, season, and edaphoclimatic conditions during the study. Averages of these parameters are presented in Table 3. 
Table 3. Total carbon (C), surface plant residue on the soil (SPR), fulvic acid (FA), humic acid (HA), humin (HU), and residual phosphorus (Pres) in the study areas. Values are averages.

\begin{tabular}{|c|c|c|c|c|c|c|}
\hline \multirow{3}{*}{ Areas } & SPR & $\mathrm{C}$ & FA & HA & HU & Pres \\
\hline & $\mathrm{Mg} \mathrm{ha}^{-1}$ & \multicolumn{4}{|c|}{-------------------- g kg $^{-1}$------------------- } & $\mathrm{mg} \mathrm{kg}^{-1}$ \\
\hline & \multicolumn{6}{|c|}{$0-0.05 \mathrm{~m}$} \\
\hline $\mathrm{NT}_{6}$ & 3.24 & 18.78 & 2.83 & 2.82 & 11.13 & 13.37 \\
\hline $\mathrm{NT}_{14}^{\circ}$ & 4.15 & 20.94 & 2.36 & 2.12 & 12.37 & 14.62 \\
\hline $\mathrm{NT}_{16+\mathrm{B}}^{14}$ & 4.73 & 18.96 & 3.21 & 2.59 & 12.52 & 14.63 \\
\hline $\mathrm{NT}_{22}$ & 3.83 & 24.02 & 4.24 & 3.72 & 15.15 & 13.11 \\
\hline \multirow[t]{2}{*}{$\mathrm{NF}$} & 14.11 & 40.78 & 3.88 & 4.15 & 28.13 & 17.37 \\
\hline & \multicolumn{6}{|c|}{$0.05-0.10 \mathrm{~m}$} \\
\hline $\mathrm{NT}_{6}$ & 3.24 & 15.90 & 2.60 & 2.55 & 8.82 & 13.42 \\
\hline $\mathrm{NT}_{14}$ & 4.15 & 16.76 & 1.95 & 1.68 & 9.83 & 13.39 \\
\hline $\mathrm{NT}_{16+\mathrm{B}}$ & 4.73 & 18.24 & 2.97 & 2.34 & 10.00 & 13.45 \\
\hline $\mathrm{NT}_{22}$ & 3.83 & 19.60 & 4.02 & 3.01 & 10.55 & 13.13 \\
\hline NF & 14.11 & 17.32 & 2.84 & 2.21 & 18.78 & 14.65 \\
\hline
\end{tabular}

* no tillage system $(\mathrm{NT})$ for 6 years $\left(\mathrm{NT}_{6}\right), 14$ years $\left(\mathrm{NT}_{14}\right), 22$ years $\left(\mathrm{NT}_{22}\right)$, or 16 years of which four included corn intercropping with Brachiaria used in interim harvest $\left(\mathrm{NT}_{16+\mathrm{B}}\right)$; and one native forest area $(\mathrm{NF})$.

Source: Rosset (2015) and Rosset et al. (2014).

The data were subjected to variance analysis using the $\mathrm{F}$ test, and averages were compared using the Student's t-test, at $p<0.05$. In all cases, preliminary analyses were performed to ensure no violation of the assumptions of normality (Lilliefors test) and homogeneity of variances (Cochran's C and Bartlett's tests). All tests were performed using the ASSISTAT software (SILVA; AZEVEDO, 2002).

\section{Results and Discussion}

The correlation matrix for the data is presented in Table 4. Significant correlations $(\mathrm{p}<5 \%)$ were observed, especially between sodium hydroxide extractable $\mathrm{Pi}(\mathrm{Pi}-\mathrm{OH})$ and $\mathrm{Po}(\mathrm{Po}-\mathrm{OH})$ and humic substances. This confirms the interaction between SOM and soil P dynamics (Table 4).

Table 4. Correlation matrix for the variables analyzed.

\begin{tabular}{|c|c|c|c|c|c|c|c|c|c|}
\hline \multirow{2}{*}{ Variables } & Pi-bic & Pt-bic & Po-bic & Pi-H & Pt-H & Po-H & $\mathrm{Pi}-\mathrm{OH}$ & $\mathrm{Pt}-\mathrm{OH}$ & Po-OH \\
\hline & \multicolumn{9}{|c|}{ ר-} \\
\hline${ }^{1} \mathrm{SPR}$ & -0.039 & -0.593 & -0.978 & -0.356 & -0.259 & 0.003 & -0.124 & 0.880* & 0.973* \\
\hline $\mathrm{C}$ & -0.014 & -0.516 & -0.890 & -0.195 & -0.175 & -0.068 & 0.066 & $0.936 *$ & $0.924 *$ \\
\hline FA & $0.722 *$ & 0.421 & -0.302 & 0.699* & $0.646^{*}$ & 0.282 & $0.841 *$ & $0.763 *$ & 0.311 \\
\hline HA & 0.378 & 0.013 & -0.554 & 0.369 & 0.244 & -0.054 & $0.609 *$ & $0.871 *$ & 0.551 \\
\hline HU & 0.048 & -0.482 & $-0.913 *$ & -0.180 & -0.134 & -0.006 & 0.072 & $0.949 *$ & $0.934 *$ \\
\hline \multirow[t]{2}{*}{ Pres } & -0.158 & -0.706 & $-0.979 *$ & -0.577 & -0.370 & 0.106 & -0.405 & $0.731^{*}$ & 0.978* \\
\hline & \multicolumn{9}{|c|}{ 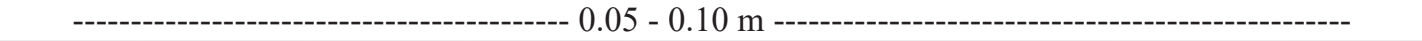 } \\
\hline SPR & -0.5050 & -0.5619 & -0.6813 & -0.7096 & -0.3056 & 0.4607 & 0.5393 & 0.3988 & 0.3656 \\
\hline $\mathrm{C}$ & $0.8850 *$ & $0.8461 *$ & $0.6477 *$ & 0.3964 & 0.7050 & 0.7453 & $0.7167 *$ & 0.8192* & 0.8331 * \\
\hline FA & $0.7468 *$ & $0.6602 *$ & 0.3343 & $0.5204 *$ & 0.8683 * & 0.8709 & $0.6759 *$ & $0.8477 *$ & $0.8759 *$ \\
\hline HA & 0.5955 & 0.5040 & 0.1779 & 0.6237 & 0.8504 & 0.6870 & $0.6463 *$ & $0.6063^{*}$ & 0.3891 \\
\hline HU & -0.4222 & -0.4846 & $-0.6280 *$ & -0.6168 & -0.1879 & 0.5464 & 0.4687 & $0.6390 *$ & $0.5022 *$ \\
\hline Pres & -0.6698 & $-0.7199 *$ & $-0.804 *$ & -0.7951 & -0.4590 & 0.2975 & 0.3485 & 0.2053 & 0.1732 \\
\hline
\end{tabular}

* Significant at $p<0.05 .{ }^{1}$ Total carbon (C), surface plant residue on the soil (SPR), fulvic acid (FA), humic acid (HA), humin (HU), and residual phosphorus (Pres). 
The areas where NT had been adopted for longer periods $\left(\mathrm{NT}_{16+\mathrm{B}}\right.$ and $\left.\mathrm{NT}_{22}\right)$ presented similar $(0-0.05 \mathrm{~m})$ or higher $(0-0.10 \mathrm{~m})$ concentrations of sodium bicarbonate extractable $\mathrm{Pt}$ (Pt-bic), and Pi (Pi-bic), than the remaining NT areas, and NF (Table 5). Labile Pi concentrations were higher for some $\mathrm{NT}$ areas $\left(\mathrm{NT}_{16+\mathrm{B}}\right.$ and $\mathrm{NT}_{22}$ for the $0-0.05 \mathrm{~m}$ soil layer, and all NT areas for the 0.05-0.10 $\mathrm{m}$ soil layer), than for NF. This was due to the P fertilization performed in NT areas. Successive applications of $\mathrm{P}$ fertilizers result in increased phosphorus lability, due to the gradual occupation of high-affinity $\mathrm{P}$ adsorption sites, and the increase in more labile $\mathrm{P}$ fractions due to successive fertilizations (BRAVO et al., 2007). Rodrigues (2013) and Bezerra et al. (2015) also observed higher labile phosphorus concentrations in NT areas when compared to a Red Latosol under native Cerrado vegetation.
The Pt-bic and Pi-bic fractions increased with increasing time of $\mathrm{NT}$, being higher for $\mathrm{NT}_{16+\mathrm{B}}$ $(0.0-0.05 \mathrm{~m})$ and $\mathrm{NT}_{22}(0.05-0.10 \mathrm{~m})$ than for $\mathrm{NT}_{6}$. This is correlated with an increase in the fulvic acid fraction (Table 4), and a possible decrease in soil adsorption capacity (GUPPY et al., 2005). The competition between phosphorus and organic acids for soil adsorption sites results in increased $\mathrm{P}$ concentrations in the soil solution. In addition, organic acids such as fulvic and humic acids may also form complexes with metal cations, such as $\mathrm{Fe}$ and $\mathrm{Al}$, decreasing the number of available adsorption sites and increasing $\mathrm{P}$ availability to plants (GUPPY et al., 2005). Because fulvic acids are more labile than other humic acids, the increase in the fulvic acid fraction with increasing time of NT (Table 3), and its subsequent mineralization, may make inorganic phosphorus available in the soil.

Table 5. Concentrations of sodium bicarbonate extractable (bic), total phosphorus (Pt), inorganic phosphorus (Pi), and organic phosphorus (Po), in different soil layers and soil management systems.

\begin{tabular}{|c|c|c|c|c|c|c|}
\hline \multirow{3}{*}{ Soil layer (m) } & \multicolumn{6}{|c|}{ System $^{1}$} \\
\hline & $\mathrm{NT}_{6}$ & $\mathrm{NT}_{14}$ & $\mathrm{NT}_{16+\mathrm{B}}$ & $\mathrm{NT}_{22}$ & $\mathrm{NF}$ & $\mathrm{CV}(\%)$ \\
\hline & \multicolumn{6}{|c|}{ Pt-bic $\left(\mathrm{mg} \mathrm{kg}^{-1}\right)$} \\
\hline $0.0-0.05$ & $30.85 b$ & $25.89 b c$ & $38.06 \mathrm{a}$ & $42.47 \mathrm{a}$ & $23.14 \mathrm{c}$ & 12.49 \\
\hline \multirow[t]{2}{*}{$0.05-0.10$} & $30.74 d$ & $43.84 c$ & $57.69 \mathrm{~b}$ & $74.00 \mathrm{a}$ & $24.04 d$ & 13.10 \\
\hline & \multicolumn{6}{|c|}{ Pi-bic $\left(\mathrm{mg} \mathrm{kg}^{-1}\right)$} \\
\hline $0.0-0.05$ & $9.40 \mathrm{c}$ & $7.07 \mathrm{c}$ & $20.43 a$ & $20.51 \mathrm{a}$ & $13.06 \mathrm{~b}$ & 15.84 \\
\hline \multirow[t]{2}{*}{$0.05-0.10$} & $15.99 \mathrm{~d}$ & $22.42 \mathrm{c}$ & $35.82 \mathrm{~b}$ & $50.01 \mathrm{a}$ & $12.02 \mathrm{e}$ & 10.75 \\
\hline & \multicolumn{6}{|c|}{ Po-bic $\left(\mathrm{mg} \mathrm{kg}^{-1}\right)$} \\
\hline $0.0-0.05$ & $21.44 \mathrm{a}$ & $20.20 \mathrm{a}$ & $18.44 \mathrm{a}$ & $21.95 \mathrm{a}$ & $10.85 b$ & 15.11 \\
\hline $0.05-0.10$ & $14.75 \mathrm{a}$ & $21.43 \mathrm{a}$ & $21.86 \mathrm{a}$ & $23.99 \mathrm{a}$ & $12.01 \mathrm{~b}$ & 21.77 \\
\hline
\end{tabular}

* Values followed by the same lower case letter within the same line are not significantly different between different soil management systems, according to the Student's t-test, at $p<0.05 .{ }^{1}$ no tillage system (NT) for 6 years $\left(\mathrm{NT}_{6}\right), 14$ years $\left(\mathrm{NT}_{14}\right), 22$ years $\left(\mathrm{NT}_{22}\right)$, or 16 years of which four included corn intercropping with Brachiaria used in interim harvest $\left(\mathrm{NT}_{16+\mathrm{B}}\right)$; and one native forest area (NF). Values are averages.

Another interesting aspect are the similar Ptbic and Pi-bic concentrations in the soil layer 0.0$0.05 \mathrm{~m}$ observed for $\mathrm{NT}_{16+\mathrm{B}}$ and $\mathrm{NT}_{22}$ (Table 5). This suggests that the 4 years of CLI for $\mathrm{NT}_{16+\mathrm{B}}$ may be accelerating the accumulation of Pt-bic and Pi-bic in this soil layer. This may result from a combination of increased SPR (Table 3), the contribution of the abundant root systems, and 
higher rhizodeposition of root exudates due to the presence of Brachiaria, maintaining the organic matter concentrations (CARNEIRO et al., 2009; SILVA JÚNIOR et al., 2009, LOSS et al., 2012), and consequently the production of humic and fulvic acids (BEZERRA et al., 2013), thereby decreasing adsorption and increasing Pi-bic.

The higher Po-bic observed more in NT areas than NF (Table 5) and resulted from the soil management over years, which increased the SOM quantity, quality, and mineralization, and increased $\mathrm{P}$ incorporation into the organic compartment. This is consistent with Santos et al. (2012), who analyzed P fractions in a dystrophic Red Latosol from areas that had been cultivated for several years, and adjacent non-cultivated areas (native Cerrado); results indicated a higher Po-bic for cultivated areas. This may also be related to decomposition of the different root systems of the adopted crops during NT establishment. Olibone and Rosolem (2010) analyzed different P fractions following phosphate application to soya crops in a system incorporating five years of NT, and also observed increased Po concentrations following the soya harvest. The authors related this to root decomposition.

A strong significant negative correlation was observed between residual phosphorus (Pres) and the Po-bic fraction for both soil layers (Table 4). This indicates that the increase in Pres decreases the Po-bic fraction, i.e., in NT areas the mineralization of the Po-bic fraction contributes to the increase in $\mathrm{P}$ availability. However, this result must be interpreted with caution, since the increase in Pres availability will depend on the type of adsorption and organic acid to which the P becomes bonded. P bonded to low molecular weight organic acids becomes more readily available, due to higher mineralization rates, whereas mineralization of high molecular weight organic acids is slower, resulting in lower $\mathrm{P}$ availability (PAVINATO; ROSOLEM, 2008;
GUPPY et al., 2005). This is shown by the positive significant correlation between Pres and Po-OH observed for the soil layer 0-0.05 m, indicating that the increase in Pres increased $\mathrm{P}$ in the $\mathrm{Po}-\mathrm{OH}$ fraction (Table 4).

Concentrations of sulfuric acid extractable Pt (Pt-H) were higher for areas with a longer NT duration $\left(\mathrm{NT}_{16+\mathrm{B}}\right.$ and $\mathrm{NT}_{22}$ for layer $0-0.05 \mathrm{~m}$, and $\mathrm{NT}_{22}$ for layer $0.05-0.10 \mathrm{~m}$ ) when compared to the remaining study areas (Table 6). Beutler et al. (2015) also observed higher concentrations of Pt-H for an NT area with CLI than for native Cerradão (transitional tropical forest). This may be attributed to the annual application of $\mathrm{P}$ fertilization, which initially resulted in increased labile inorganic $\mathrm{P}$ fractions, and then in increased moderately labile $\mathrm{P}$ fractions over time, as a result of $\mathrm{P}$ adsorption to iron and aluminum oxides through inner-sphere complex formation (SOUZA, 2008).

The sulfuric acid extractable $\mathrm{Pi}(\mathrm{Pi}-\mathrm{H})$ fraction increased with increasing NT duration, in that the two oldest NT areas presented higher Pi-H fractions than NF for the two soil layers evaluated (Table 6). This indicates that with increasing time of NT, phosphorus fertilization may saturate the adsorption sites available to the labile Pi fraction (Pi-bic), and increase Pi accumulation in the moderately labile fraction (Pi-H), when NT reaches the maintenance phase. Rotta (2012) observed similar results for areas with 7, 11, and 16 years of NT in Cerrado regions, and considered that the increase in labile and moderately labile Pi fractions with increasing NT durations may help decrease applications of phosphorus fertilization, since over time the soil will begin a continuous process of natural depletion, resulting in better fertilizer retention and efficiency. The lower Pi-H observed for NF than for the older NT areas may also be related to the absence of phosphorus fertilization in NF, since the moderately labile $\mathrm{P}$ may act as $\mathrm{P}$ source in NF, meeting the forest $\mathrm{P}$ needs (NOVAIS et al., 2007). 
Table 6. Concentrations of extractable sulfuric acid $(\mathrm{H})$, total phosphorus $(\mathrm{Pt})$, inorganic phosphorus $(\mathrm{Pi})$, and organic phosphorus (Po), in different soil layers and soil management systems.

\begin{tabular}{|c|c|c|c|c|c|c|}
\hline \multirow{3}{*}{ Soil layer (m) } & \multicolumn{6}{|c|}{ System $^{1}$} \\
\hline & $\mathrm{NT}_{6}$ & $\mathrm{NT}_{14}$ & $\mathrm{NT}_{16+\mathrm{B}}$ & $\mathrm{NT}_{22}$ & $\mathrm{NF}$ & $\mathrm{CV}(\%)$ \\
\hline & \multicolumn{6}{|c|}{ Pt-H $\left(\mathrm{mg} \mathrm{kg}^{-1}\right)$} \\
\hline $0.0-0.05$ & $679.30 b$ & $695.04 b$ & $868.61 \mathrm{a}$ & $937.83 a$ & $714.60 \mathrm{~b}$ & 7.26 \\
\hline \multirow[t]{2}{*}{$0.05-0.10$} & $574.46 \mathrm{~b}$ & $531.43 b$ & $542.43 b$ & $712.08 \mathrm{a}$ & $544.94 b$ & 6.21 \\
\hline & & \multicolumn{5}{|c|}{$\mathrm{Pi}-\mathrm{H}\left(\mathrm{mg} \mathrm{kg}^{-1}\right)$} \\
\hline $0.0-0.05$ & $491.88 b c$ & $437.13 d$ & $525.75 b$ & $653.64 a$ & $459.94 c d$ & 6.44 \\
\hline \multirow[t]{2}{*}{$0.05-0.10$} & $407.02 \mathrm{~b}$ & $385.24 b$ & $351.08 \mathrm{c}$ & $470.65 a$ & $317.25 \mathrm{~d}$ & 5.76 \\
\hline & & \multicolumn{5}{|c|}{ Po-H (mg kg $\left.{ }^{-1}\right)$} \\
\hline $0.0-0.05$ & $187.42 \mathrm{c}$ & $257.91 b c$ & $342.86 a$ & $284.19 \mathrm{ab}$ & $254.66 \mathrm{bc}$ & 20.95 \\
\hline $0.05-0.10$ & $167.45 \mathrm{c}$ & $146.18 \mathrm{c}$ & $191.35 b c$ & $241.42 \mathrm{a}$ & $227.68 \mathrm{ab}$ & 18.51 \\
\hline
\end{tabular}

* Values followed by the same lower case letter within the same line are not significantly different between different soil management systems, according to the Student's t-test, at $p<0.05 .{ }^{1}$ no tillage system (NT) for 6 years $\left(\mathrm{NT}_{6}\right), 14$ years $\left(\mathrm{NT}_{14}\right), 22$ years $\left(\mathrm{NT}_{22}\right)$, or 16 years of which four included corn intercropping with Brachiaria used in interim harvest $\left(\mathrm{NT}_{16+\mathrm{B}}\right)$; and one native forest area (NF). Values are averages.

Similarly to Pi-bic, Pi-H and Pt-H were also significantly positively $(p<5 \%$ ) correlated with the fulvic acid fraction for the two soil layers evaluated (Table 4). This shows the important contribution of this SOM humic fraction to the availability of inorganic phosphorus in the soil of the studied areas.

Higher sulfuric acid extractable Po $(\mathrm{Po}-\mathrm{H})$ fractions were observed for $\mathrm{NT}_{16+\mathrm{B}}(0-0.05 \mathrm{~m})$ and $\mathrm{NT}_{22}(0.05-0.10 \mathrm{~m})$ than for $\mathrm{NT}_{6}$, and for areas with longer NT duration $\left(\mathrm{NT}_{16+\mathrm{B}}\right.$ and $\left.\mathrm{NT}_{22}\right)$ than for $\mathrm{NF}$ (0-0.05 m) (Table 6). The Po-H fraction therefore increased with increasing time of NT, indicating that NT areas accumulate more recalcitrant organic material over time (Table 3), such as humic acids, which are more difficult to degrade by soil microorganisms. Soil $\mathrm{P}$ therefore becomes adsorbed to humic acids, and is accumulated at the Po-H fraction (GONÇALVES; MEURER, 2009).
Sodium hydroxide extractable $\mathrm{Pt}(\mathrm{Pt}-\mathrm{OH})$ increased with increasing NT duration. However, the Pt-OH fraction was higher for NF than for all NT areas for the $0-0.05 \mathrm{~m}$ soil layer, and higher than for $\mathrm{NT}_{6}, \mathrm{NT}_{14}$, and $\mathrm{NT}_{16+\mathrm{B}}$ for the $0.05-0.10$ $\mathrm{m}$ soil layer (Table 7). The increase in the $\mathrm{Pt}-\mathrm{OH}$ fraction with increasing NT duration was due to the older NT areas having received more phosphorus fertilization over time, increasing the Pi specific adsorption to $\mathrm{Fe}$ and $\mathrm{Al}$ oxides (ROTTA, 2012). The higher Pt-OH fraction for NF, when compared to NT areas for the two soil layers, may be explained by the high positive significant correlations between this fraction and the $\mathrm{C}$, humic acid, and humin concentrations (Table 4). This indicates that a large part of $\mathrm{P}$ in the forest soil was adsorbed to more recalcitrant organic fractions, which was confirmed by the higher Po than Pi concentrations observed for NF. 
Table 7. Concentrations of extractable sodium hydroxide $(\mathrm{OH})$, total phosphorus (Pt), inorganic phosphorus (Pi), and organic phosphorus (Po), in different soil layers and soil management systems.

\begin{tabular}{ccccccc}
\hline \multirow{2}{*}{ Soil layer $(\mathrm{m})$} & \multicolumn{7}{c}{ System $^{1}$} \\
\cline { 2 - 7 } & $\mathrm{NT}_{6}$ & $\mathrm{NT}_{14}$ & $\mathrm{NT}_{16+\mathrm{B}}$ & $\mathrm{NT}_{22}$ & $\mathrm{NF}$ & $\mathrm{CV}(\%)$ \\
\cline { 2 - 6 } & \multicolumn{7}{c}{ Pt-OH $\left(\mathrm{mg} \mathrm{kg}^{-1}\right)$} \\
\hline $0.0-0.05$ & $56.65 \mathrm{c}$ & $60.62 \mathrm{c}$ & $64.35 \mathrm{bc}$ & $71.79 \mathrm{~b}$ & $84.96 \mathrm{a}$ & 11.20 \\
$0.05-0.10$ & $33.84 \mathrm{~d}$ & $35.47 \mathrm{~d}$ & $46.08 \mathrm{c}$ & $75.06 \mathrm{a}$ & $63.39 \mathrm{~b}$ & 3.68 \\
\hline & & \multicolumn{7}{c}{$\mathrm{Pi}-\mathrm{OH}\left(\mathrm{mg} \mathrm{kg}^{-1}\right)$} \\
\hline $0.0-0.05$ & $32.95 \mathrm{bc}$ & $28.01 \mathrm{c}$ & $33.02 \mathrm{~b}$ & $44.55 \mathrm{a}$ & $33.24 \mathrm{~b}$ & 10.92 \\
$0.05-0.10$ & $21.89 \mathrm{~b}$ & $23.81 \mathrm{~b}$ & $23.87 \mathrm{~b}$ & $29.07 \mathrm{a}$ & $28.40 \mathrm{a}$ & 6.45 \\
\hline & & \multicolumn{7}{c}{ Po-OH $\left(\mathrm{mg} \mathrm{kg}^{-1}\right)$} \\
\hline $0.0-0.05$ & $23.69 \mathrm{~b}$ & $32.61 \mathrm{~b}$ & $31.33 \mathrm{~b}$ & $27.23 \mathrm{~b}$ & $51.72 \mathrm{a}$ & 25.49 \\
$0.05-0.10$ & $11.94 \mathrm{~d}$ & $11.66 \mathrm{~d}$ & $22.20 \mathrm{c}$ & $45.99 \mathrm{a}$ & $34.99 \mathrm{~b}$ & 11.27 \\
\hline
\end{tabular}

* Values followed by the same lower case letter within the same line are not significantly different between different soil management systems, according to the Student's t-test, at $p<0.05 .{ }^{1}$ no tillage system $(\mathrm{NT})$ for 6 years $\left(\mathrm{NT}_{6}\right), 14$ years $\left(\mathrm{NT}_{14}\right), 22$ years $\left(\mathrm{NT}_{22}\right)$, or 16 years of which four included corn intercropping with Brachiaria used in interim harvest $\left(\mathrm{NT}_{16+\mathrm{B}}\right)$; and one native forest area (NF). Values are averages.

Pi-OH also increased with increasing time of NT, with $\mathrm{NT}_{22}$ presenting higher $(0-0.05 \mathrm{~m})$ or similar $(0.05-0.10 \mathrm{~m}) \mathrm{Pi}-\mathrm{OH}$ than NF (Table 7). As discussed above, this may be due to the accumulated fertilization in older NT areas, which temporarily stabilizes the electrical charges of iron and aluminum oxides at the soil surface, increasing the Pi fraction (BEUTLER et al., 2015). Significant positive correlations were also observed between the Pi-OH fraction and fulvic and humic acids, indicating that these humic fractions may act both as a soil P source and sink. Bezerra et al. (2015) also reported significant correlations between the $\mathrm{Pi}-\mathrm{OH}$ fraction and fulvic acids.

Po-OH concentrations were higher for NF than for all NT areas for the $0-0.05 \mathrm{~m}$ soil layer, and for $\mathrm{NT}_{6}, \mathrm{NT}_{14}$, and $\mathrm{NT}_{16+\mathrm{B}}$ for the $0.05-0.10 \mathrm{~m}$ soil layer (Table 7). This is also clearly indicated by the strong correlations of this fraction with SPR, $\mathrm{C}$, and humin (Table 4), indicating that the higher SPR accumulation due to litter deposition in NF results in increased soil $\mathrm{C}$ concentration. This is especially true for the humin fraction, which results in increased Po-OH fractions, since part of the soil
$\mathrm{P}$ in NF is adsorbed to, and accumulated in, the most recalcitrant fraction of SOM.

It should also be noted that most of the total $\mathrm{P}$ in soil of NT areas was moderately labile (soil layer $0-0.05 \mathrm{~m}: 88.59 \%$ for $\mathrm{NT}_{6}, 88.93 \%$ for $\mathrm{NT}_{14}, 89.45 \%$ for $\mathrm{NT}_{16+\mathrm{B}}$, and $89.14 \%$ for $\mathrm{NT}_{22}$; soil layer $0.05-0.10 \mathrm{~m}: 89.89 \%$ for $\mathrm{NT}_{6}, 87.01$ $\%$ for $\mathrm{NT}_{14}, 83.94 \%$ for $\mathrm{NT}_{16+\mathrm{B}}$, and $82.69 \%$ for $\mathrm{NT}_{22}$ ), and inorganic (soil layer 0-0.05 m: 64.15 $\%$ for $\mathrm{NT}_{6}, 55.93 \%$ for $\mathrm{NT}_{14}, 54.14 \%$ for $\mathrm{NT}_{16+\mathrm{B}}$, and $62.13 \%$ for $\mathrm{NT}_{22}$; soil layer $0.05-0.10 \mathrm{~m}$ : $53.08 \%$ for $\mathrm{NT}_{6}, 49.29 \%$ for $\mathrm{NT}_{14}, 36.16 \%$ for $\mathrm{NT}_{16+\mathrm{B}}$, and $44.73 \%$ for $\mathrm{NT}_{22}$ ). This is due to the annual application of phosphorus fertilizers, with P first becoming preferentially associated with the inorganic labile fraction, and over time becoming adsorbed to iron and aluminum oxides through an inner-sphere complex formation, increasing the moderately labile inorganic fraction (SOUZA, 2008). This is consistent with Beutler et al. (2015), who evaluated a CLI area with Red Latosol, in Montividiu state of Goiás, and also observed predominance of the moderately labile $\mathrm{P}$ fraction (70\% Pt) and inorganic P (95\%). 


\section{Conclusions}

The management of phosphorus fertilization and soil organic matter in NT results in increased concentration of all inorganic $\mathrm{P}$ fractions $(0-0.10 \mathrm{~m})$, as well as labile $(0.05-0.10 \mathrm{~m})$, moderately labile (0-0.10 m), and moderately recalcitrant (0.05-0.10 $\mathrm{m})$ organic phosphorus fractions, with increasing time of NT ( 6 to 22 years).

Interactions were observed between the soil properties evaluated, especially between the inorganic phosphorus fractions and fulvic and humic acids, and between moderately recalcitrant organic phosphorus and the humin fraction.

\section{Acknowledgments}

To farmers by the availability of areas for the study.

To CAPES (Coordination for the Improvement of Higher Education Personnel), for financial support.

To CNPq (National Council for Scientific and Technological Development), for financial support (Chamada Universal - MCTI/CNPQ N ${ }^{\circ}$ 14/2012) and award for excellence in research to the authors.

\section{References}

BEUTLER, S. J. Matéria orgânica do solo e fósforo orgânico em área de integração lavoura-pecuária no cerrado goiano. 2012. Dissertação (Mestrado em Agronomia) - Universidade Federal Rural do Rio de Janeiro, Seropédica.

BEUTLER, S. J.; PEREIRA, M. G.; LOSS, A.; PERIN, A.; ANJOS, L. H. C. Humic substances and phosphorus fractions in areas with crop-livestock integration, pasture and natural cerrado vegetation in Goiás, Brazil. Tropical and Subtropical Agroecosystems, Mérida, v. 18, n. 1, p. 11-25, 2015.

BEZERRA, R. P. M.; LOSS, A.; PEREIRA, M. G.; PERIN, A. Formas de carbono em latossolo sob sistemas de plantio direto e integração lavoura-pecuária no cerrado, Goiás. Semina: Ciências Agrárias, Londrina, v. 34, n. 6, p. 2637-2654, 2013.
Frações de fósforo e correlação com atributos edáficos sob sistemas de plantio direto e integração lavoura-pecuária no Cerrado Goiano. Semina: Ciências Agrárias, Londrina, v. 36, n. 3, p. 1287-1306, 2015.

BHERING, S. B.; SANTOS, H. G. dos. (Ed.). Mapa de solos Estado do Paraná: legenda atualizada. Embrapa Solos. 2. ed. Rio de Janeiro: Embrapa Florestas, Colombo, PR, 2008. 74 p. (1 mapa escala 1: 600.000; formato A0. Contém Mapa de Solos do Estado do Paraná, escala 1:600. 000. Edição atualizada de acordo com o Sistema de Classificação de Solos).

BOWMAN, R. A. A sequential extraction procedure with concentrated sulfuric acid and dilute base for soil organic phosphorus. Soil Science Society of America Journal, Madison, v. 53, n. 2, p. 362-366, 1989.

BOWMAN, R. A.; COLE, C. V. An exploratory method for fractionation of organic phosphorus from grassland soils. Soil Science, Baltimore, v. 125, n. 2, p. 95-101, 1978.

BRAVO, C. A.; GIRALDEZ, J. V.; ORDOÑEZ, R.; GONZALEZ, P.; TORRES, F. P. Long term influence of conservation tillage on chemical properties of surface horizon and legume crops yield in a Vertisol of Southern Spain. Soil Science, Baltimore, v. 172, n. 2, p. 141-148, 2007.

CARNEIRO, L. F.; RESENDE, A. V.; FURTINI NETO, A. E.; SANTOS, J. Z. L.; CURI, N.; REIS, T. H. P.; VALLE, L. A. R. Frações de fósforo no solo em resposta à adubação fosfatada em um Latossolo com diferentes históricos de uso. Revista Brasileira de ciência do solo, Viçosa, MG, v. 35, n. 2, p. 483-491, 2011.

CARNEIRO, M. A. C.; SOUZA, E. D. de; REIS, E. F. dos; PEREIRA, H. S.; AZEVEDO, W. R. Atributos físicos, químicos e biológicos de solo de cerrado sob diferentes sistemas de uso e manejo. Revista Brasileira de Ciência do Solo, Viçosa, MG, v. 33, n. 1, p. 147-157, 2009.

DUDA, G. P. Conteúdo de fósforo microbiano, orgânico e biodisponível em diferentes classes de solo. 2000. Tese (Doutorado em Agronomia) - Universidade Federal Rural do Rio de Janeiro, Seropédica.

DUDA, G. P.; GUERRA, J. G. M.; PEREIRA, M. G.; ANJOS, L. H. C.; RIBEIRO, M. R. Avaliação da biodisponibilidade de fósforo em diferentes classes de solos do Brasil. Semina: Ciências Agrárias, Londrina, v. 34, n. 4, p. 1563-1576, 2013.

EMPRESA BRASILEIRA DE PESQUISA AGROPECUÁRIA - EMBRAPA. Manual de métodos de análise de solo. 2. ed. Rio de Janeiro: Embrapa Solos, 1997. $212 \mathrm{p}$. 
Sistema brasileiro de classificação de solos. 3 . ed. Rio de Janeiro: Embrapa Solos, 2013. 353 p.

GALVANI, R.; HOTTA, L. F. K.; ROSOlEM, C. A. Phosphorus sources and fractions in an Oxisol under notilled soybean. Scientia Agricola, Piracicaba, v. 65, n. 4, p. 415-421, 2008.

GATIBONI, L. C.; KAMINSKI, J.; RHEINHEIMER, D. S.; KAMINSKI, J.; FLORES, J. P. C. Biodisponibilidade de formas de fósforo acumuladas em solo sob sistema plantio direto. Revista Brasileira de Ciência do Solo, Viçosa, MG, v. 31, n. 4, p. 691-699, 2007.

GONÇALVES, G. K.; MEURER, E. J. Frações de fósforo no solo e sua relação com a absorção pelas plantas de arroz irrigado por alagamento em solos do rio grande do sul. Revista Brasileira de Ciência do Solo, Viçosa, MG, v. 33, n. 2, p. 357-362, 2009.

GUPPY, C. N.; MENZIES, N. W.; MOODY, P. W.; BLAMEY, F. P. C. Competitive sorption reactions between phosphorus and organic matter in soil: A review. Australian Journal of Soil Research, Melbourne, v. 43, n. 1, p. 189-202, 2005.

LOSS, A.; PEREIRA, M. G.; PERIN, A.; ANJOS, L. H C. Carbon and nitrogen content and stock in no-tillage and crop-livestock integration systems in the Cerrado of Goias State, Brazil. Journal of Agricultural Science, Toronto, v. 4, n. 8, p. 96-105, 2012.

NOVAIS, R. F.; SMYTH, T. J.; NUNES, F. N. Fósforo. In: NOVAIS, R. F.; ALVAREZ V., V. H.; BARROS, N. F.; FONTES, R. L. F.; CANTARUTTI, R. B.; NEVES, J. C. L. Fertilidade do solo. Viçosa, MG: Sociedade Brasileira de Ciência do Solo, 2007. p. 471-537.

OLIBONE, D.; ROSOLEM, C. A. Phosphate fertilization and phosphorus forms in an Oxisol under no-till. Scientia Agricola, Piracicaba, v. 67, n. 4, p. 465-471, 2010.

OLIVEIRA, R. I.; GAMA-RODRIGUES, A. C.; GAMA-RODRIGUES, E. F.; ZAIA, F. C.; PEREIRA, M. G.; FONTANA, A. Fósforo orgânico em horizontes diagnósticos superficiais de diferentes classes de solo. Revista Brasileira de Ciência do Solo, Viçosa, MG, v. 38, n. 1, p. 1411-1420, 2014.

PARTELLI, F. L.; BUSATO, J. B.; VIEIRA, H. D.; VIANA, A. P.; CANELLAS, L. P. Qualidade da matéria orgânica e distribuição do fósforo no solo de lavouras orgânicas de café Conilon. Ciência Rural, Santa Maria, v. 39, n. 7, p. 2065-2072, 2009.

PAVINATO, P. S.; ROSOLEM, C. A. Disponibilidade de nutrientes no solo - decomposição e liberação de compostos orgânicos de resíduos vegetais. Revista Brasileira de Ciência do Solo, Viçosa, MG, v. 32, n. 3, p. 911-920, 2008.
RODRIGUES, M. Sistemas de manejo e a dinâmica das formas de fósforo e da fertilidade em solos de Cerrado. 2013. Dissertação (Mestrado em Agronomia) - Escola Superior de Agricultura Luiz de Queiroz, Piracicaba.

ROSSET, J. S. Caracterização da matéria orgânica, atributos químicos e físicos do solo sob diferentes sistemas de manejo na região oeste do Paraná. 2015. Tese (Doutorado em Agronomia) - Universidade Estadual do Oeste do Paraná, Marechal Candido Rondon.

ROSSET, J. S.; LANA, M. C.; PEREIRA, M. G.; SCHIAVO, J. A.; RAMPIM, L.; SARTO, M. V. M.; SEIDEL, E. P. Estoque de carbono, propriedades químicas e físicas do solo em sistemas de manejo com diferentes tempos de implantação na Região Oeste do Paraná, Brasil. Semina: Ciências Agrárias, Londrina, v. 35, n. 6, p. 3053-3072, 2014.

ROTTA, L. R. Fracionamento e disponibilidade de fósforo em uma cronossequência de cultivos sob plantio direto. 2012. Dissertação (Mestrado em Agronomia) Universidade Federal de Goiás, Jataí.

SANTOS, D. R.; GATIBONI, L. C.; KAMINSKI, J. Fatores que afetam a disponibilidade do fósforo e o manejo da adubação fosfatada em solos sob sistema plantio direto. Ciência Rural, Santa Maria, v. 38, n. 2, p. 576-586, 2008.

SANTOS, J. Z. L.; FURTINI NETO, A. E.; RESENDE, A. V.; CARNEIRO, L. F.; CURI, N. Frações de fósforo e carbono orgânico em latossolos de cerrado sob diferentes usos. In: FERTBIO, 2012, Maceió. Anais... Maceio: FERTBIO, 2012. p. 4.

SILVA, A. A.; NÓBREGA, J. C.A.; CURI, N.; SIQUEIRA, J. O.; SÁ, J. J. G.; MARQUES, M.; MOTTA, P. E. F. Frações de fósforo em Latossolos. Pesquisa Agropecúaria Brasileira, Brasília, v. 38, n. 10, p. 1197-1207, 2003.

SILVA, F. A. S.; AZEVEDO, C. A. V. Versão do programa computacional Assistat para o sistema operacional Windows. Revista Brasileira de Produtos Agroindustriais, Campina Grande, v. 4, n. 1, p. 71-78, 2002.

SILVA JÚNIOR, M. L. da; DESJARDINS, T.; SARRAZIN, M.; MELO, V. S. de; MARTINS, P. F.; SANTOS, E. R.; CARVALHO, C. J. R. Carbon content in Amazonian Oxisols after Forest conversion to pasture. Revista Brasileira de Ciência do Solo, Viçosa, MG, v. 33, n. 6, p. 1603-1611, 2009.

SOUZA, E. D. Evolução da matéria orgânica, do fósforo e da agregação do solo em sistema de integração agricultura-pecuária em plantio direto, submetido a intensidades de pastejo. 2008. Tese (Doutorado em Agronomia) - Universidade Federal do Rio Grande do Sul, Porto Alegre. 